\author{
MIROSŁAWA HUFLEJT-ŁUKASIK ${ }^{\mathrm{a}}$ \\ WACŁAW BĄK ${ }^{\mathrm{b}}$ \\ RAFAŁ STYŁA ${ }^{\mathrm{a}}$ \\ KRZYSZTOF KLAJS ${ }^{\mathrm{c}}$ \\ ${ }^{\text {a }}$ University of Warsaw \\ Faculty of Psychology \\ ${ }^{\mathrm{b}}$ The John Paul II Catholic University of Lublin \\ Institute of Psychology \\ ${ }^{\mathrm{c}}$ Polish Ericksonian Instiute
}

\title{
CHANGES IN THE SELF IN THE COURSE OF PSYCHOTHERAPY
}

The article is devoted to how the process and effects of psychotherapy may be analyzed and understood from the point of view of research on self-concept. Based on an analysis of the literature and their own clinical experience, the authors try to answer the following four research questions: (1) What does the change in self-concept in the course of psychotherapy consist in? (2) What is it that changes in self-concept: the structure, the content, or both? What are the mechanisms of the change? (3) What effects do changes in the self bring for the client's functioning? (4) Is it possible for a change to occur in the course of psychotherapy without being accompanied by a change in the self? In order to answer these questions, a review of empirical research on changes in the content and structure of the self is carried out. The authors present the findings of studies referring, for example, to concepts such as: compartmentalization (Showers), self-complexity (Linville), objective self-awareness (Duval), possible selves (Markus), or self-concept clarity (Campbell). The final part of the article presents conclusions for practitioners. The highlighted issues include the building of a complete and generally positive self-concept, with those negative elements that bring more complete self-knowledge and give a direction to a person's development. It is remarked that a change in the content of the self carries with it a change in self-structure, the latter being more strongly linked to adjustment and mental health than content change itself. The authors emphasize

Corresponding address: MiRosŁAWA HufLeJT-ŁUKASIK - Faculty of Psychology, University of Warsaw, ul. Stawki 5/7, 00-183 Warszawa; e-mail: Miroslawa.Huflejt-Lukasik@engram.psych. uw.edu.pl

The work on the present article was co-financed from BST resources no. 167815/2013 and from DSM resources no. 109029/2014, allocated to the Faculty of Psychology of the University of Warsaw. 
the protective role of positive future self-concept and point out that if the precondition of mental health and effective self-regulation is up-to-date and extensive self-knowledge, then psychotherapy by definition involves change in the self.

Keywords: self-concept, the content of the self, self-structure, the effectiveness of psychotherapy, the process of psychotherapy.

\section{ASPECTS OF SELF-CONCEPT}

The concept of the self has been present in psychology since the works of William James. The highest growth of interest in these issues began in the 1970s, when the self was looked at as a cognitive representation (Markus, 1977). Many definitions exist (cf. e.g., Leary \& Tangney, 2003) and many areas associated with the self are studied. It is difficult to give just one meaning to the term "self." Nor is there an entirely clear answer to the question of where the borders of the self lie in the psyche. In the present paper, the self is defined as a cognitive representation - that is, as structured knowledge about oneself (Markus, 1977). Being a system of cognitive schemas, the self selects information from the environment, modifies it, and stores it in memory. It influences behavior, regulating the person's actions. It also determines plans and sets the standards of behavior. It works as a kind of map that makes orientation possible and at the same time integrates the person's functioning. Self-concept, then, controls the processing of information concerning the self as well as plays adaptive and regulatory functions. It also enables conscious self-reflection. The self is a dynamic system that can be described in terms of content, structure, and processes connected with changes in the self, also in its relations with the environment (Huflejt-Łukasik, 2010).

\section{The content of the self}

The contents in the self concern what kind of person one is, the traits and dispositions attributed to oneself, the beliefs regarding one's own appearance, or the way of building relationships with others. Self-concept comprises a substantial amount of information that the person has accumulated in the course of his or her life and that may undergo modifications. At a particular moment, only a part of the information related to oneself is active. This information has been termed working self-concept (Markus \& Wurf, 1987). Elements of self-concept differ in terms of cognitive availability. In certain circumstances, a particular kind of self-concept may manifest itself; for example, in difficult situations 
working self-concept may be dominated by negative contents. The idea of working self-concept makes it possible to understand the stability inherent in self-representation as well as its variability (Markus, 1977; Markus \& Nurius, 1986).

Among theories organizing the contents comprised in the self, the ones relevant to the understanding of changes in the self are those that take into account the time perspective, including the person's life goals (cf. Huflejt-Łukasik, 2010). One of the main theories of this kind is the self-discrepancy theory (Higgins, 1987). It divides the self into three separate self-concepts: actual, ideal, and ought selves. The comparison of the actual self with one of the self-guides (i.e., one of the selves that represent the direction of a person's strivings), namely the ideal self or the ought self, influences the individual's emotions and motivations.

Another theory is the possible selves theory (Markus \& Nurius, 1986). A possible self is a large set of imagined visions of oneself, which - though based on past experience - have a clear reference to the future (Erikson, 2007; Hoyle \& Sherrill, 2006). Such selves are cognitive representations of hopes, fears, and fantasies regarding oneself. A person may generate many possible selves, not only referring to different areas of functioning but also within one such area. Possible selves comprise references to positively valued states as well as to those that a person would rather avoid. Possible selves, then, comprise the goals that a person sets themselves - goals to achieve or avoid: in other words, positive and negative self-standards (Bak, 2014). However, they are not sets of abstract traits but always have the form of highly individualized and personal conceptions of oneself, referring to a specific role, situation, or context.

Generally speaking, future self-concepts - falling within the concept of selfstandards (e.g., the ideal self, the ought self), also called self-guides (HuflejtŁukasik, 2010; Strauman, 1996) - are those aspects of self-knowledge that comprise a person's goals and strivings, determining the direction of the self's development. Thus, the desired future self-concept reflects the person's potential development and change.

\section{The structure of the self}

The basic structural characteristics of the self are the following: (1) differentiation, meaning the number of dimensions a person uses in thinking about themselves, and (2) integration, meaning the degree to which the structure is a unity (Campbell, Assananad, \& Di Paula, 2003, 2004). As the person develops, hierarchy and links between different areas of the self grow weaker whereas integration and links between similar areas grow stronger (Marsh \& Ayotte, 2003). Hier- 
archy within the self reflects the extent to which a given self-concept is general or specific. The higher a given aspect of the self is in the hierarchy, the greater its potential significance for a person. Aspects of the self within the same level of the hierarchy differ in importance also depending on the strength of their influence on a higher-level aspect or depending on the number of aspects they are related to (cf. Carver \& Scheier, 1998; Huflejt-Łukasik, 2010).

Analyzing these issues, it is possible to name the following concepts and indicators related to self-structure.

(1) The indicator of self-structure differentiation is self-complexity (Linville, 1985, 1987). The more aspects with various contents the self comprises and the more of them are independent of one another, the higher the self-complexity. What is also important here is the richness of content within each aspect.

(2) Self-concept clarity is an example of a concept describing self-structure integration. Self-concept clarity specifies the extent to which the content of an individual self-concept is defined with clarity and certainty, internally consistent, and stable in time (Campbell et al., 1996).

(3) Compartmentalization is an example of a concept describing self-structure, though it is difficult to say whether it refers more to differentiation or to integration. Some believe that it is a theory presenting another dimension on which self-structure can be described (Campbell, Assananad, \& Di Paula, 2003). Compartmentalization specifies the degree to which positive and negative traits are assigned to separate clusters describing the same aspect of the self (Showers, 1992; Showers \& Kling, 1996). This theory describes evaluatively integrated thinking. Evaluative integration means establishing links between pieces of information that have opposite valuations. A person may thus have self-perception relatively independent of the number of positive and negative self-beliefs. When their number is similar, what matters is which pieces of information are important and how they are linked (Huflejt-Łukasik, 2010).

\section{RESEARCH QUESTIONS}

In the context of the application of scientific knowledge about the self, the following questions concerning changes in the self in the course of psychotherapy come to mind:

1. What does the change in self-concept in the course of psychotherapy consist in? 
2. What is it that changes in self-concept: the structure, the content, or both? What change mechanisms are involved and what are the conditions for the change to take place?

3. What effects do changes in the self bring for the client's functioning?

4. Is it possible for a change to occur in the course of psychotherapy without being accompanied by a change in the self?

Answers to these questions will allow us to better understand the essence and mechanisms of psychotherapeutic interventions. They may also be helpful in refining the standard of psychotherapist's conduct, including the conditions necessary and crucial for changes in self-concept, and in adjusting therapeutic interventions to the needs and profile of the client.

\section{THE RESULTS OF RESEARCH ON CHANGE IN THE SELF}

Looking for answers to the above questions, we will be referring to the results of research concerning the content, structure, and dynamic processes connected with the self.

\section{The self and psychological adjustment}

Research shows that the measures of differentiation and integration of the self are independent of each other (Campbell, Assananad, \& Di Paula, 2003; Suchańska \& Worach, 2013). Based on a review of theories and studies concerning the self, it seems that hierarchical self-structure, meaning the existence of an integrated central self-concept and at the same time the complexity of representations referring to various situations, is the most conducive to a person's health (Showers \& Zeigler-Hill, 2003). According to research results, the central self-concept, occupying the top position in self-structure, is the most stable. The more peripheral the aspects of the self, meaning the lower they are in the hierarchy, the more specific, situation-dependent, and prone to change the self-concept becomes. This kind of structure allows a person to adapt to situations while maintaining integration of the self (cf. Huflejt-Łukasik, 2010). Even though the content and structure of the self are mutually interdependent (Campbell, Assananad, \& Di Paula, 2003), self-structure is more strongly connected with a person's capabilities of adapting to changes as well as with his or her adjustment and mental health. Thanks to self-structure and thanks to the self being 
organized in some way, there is continuity in the self - the basis of its consistency. The consistency or integration of the self is one of the signs of mental health - it enables development and the realization of individual goals (Rogers, 1984).

Campbell, Assananad, and Di Paula (2004) conclude on the basis of a research review that measures of integration of the self show stable relations with adjustment. In the case of measures of differentiation of the self, such relations occur but they are more complex. In their research, Showers, Abramson, and Hogan (1998) demonstrated that changes in the content of the self reflect what happens in a person's life, whereas changes in self-structure are related to attempts at reducing the effects of stress. Greater compartmentalization (i.e., the degree to which positive and negative traits are assigned to separate groups describing the same aspect of the self) in stressful conditions helps isolate the negative aspects of the self - reduce their influence on self-esteem and mood. The results of Linville's (1987) study show that organizing self-knowledge into many relatively independent elements is a factor that buffers the impact of stress-causing life events as well as prevents depression and other disorders. Other researchers refined those findings, demonstrating that there is a relationship between the complexity of negative aspects of the self and the lack of adjustment (Morgan \& Janoff-Bulmann, 1994), low self-esteem, susceptibility to stress, and psychopathological symptoms (Gara et al., 1993; Wollfolk et al., 1995). At the same time, the complexity of positive aspects of the self constitutes a factor that buffers the harmful impact of stress (Campbell, Assananad, \& Di Paula, 2003, 2004).

\section{The variability and significance of self-standards}

As far as possible selves are concerned, including self-standards, the available empirical data point not only to their stability but also to their variability (Markus \& Nurius, 1986). In a situation of discrepancy between the actual self and a self-standard, the person experiences emotional discomfort, which motivates him or her to make attempts to reduce the discrepancy. In the classic version of the objective self-awareness theory (Duval \& Wicklund, 1972) self-standards were treated as relatively stable. It was believed that, out of two theoretically possible ways of reducing the discrepancy, the more probable one was a change in behavior towards adjusting it to the standard rather than a change in the standard towards greater compatibility with the actual self. Subsequent studies, however, suggest that a change in the standard is possible. Still, in order to modify a standard (which may generate excessive and unrealistic expectations from oneself and thus be the cause of problems such as depression), it is neces- 
sary to divert attention from the present unsatisfactory condition of the self and focus on the standard itself. Such a shift of focus gives the possibility of reflecting on the standard, and this reflection may in turn stimulate its modification (Duval \& Lalwani, 1999; Silvia \& Duval, 2001).

Research proving the susceptibility of future selves to change shows not only their stability but also their situational variability. Frazier and colleagues (2000) carried out longitudinal research over a period of 5 years, and the findings point to a relatively high stability of possible selves. On the other hand, Strauss and Goldberg (1999) demonstrated that entering a new role in life significantly changed the repertoire of possible selves. Their research concerned changes in the self connected with entering the role of a father (the first child) and revealed that the situation not only resulted in the emergence of new possible selves in this new area but also promoted real (behaviorally observable) commitment to upbringing. This finding is consistent with the thesis of Markus and Nurius (1986), who emphasize that possible selves are largely determined by the situational context. A change of situation promotes changes in the repertoire of possible selves, and this in turn influences adaptation to the new situation.

Research results also confirm that the contents of the actual self are more prone to change than those of the ideal self or the ought self. The future self, as that which determines the direction of development, is the most stable (e.g., Strauman, 1996). The actual self changes with new experiences and with new information. It is a prerequisite of health that contents in the self are updated as well as internalized and integrated within the self (Rogers, 1984). Thus, both variability and stability of the self are ensured. Also the size and type of discrepancy between the actual self and self-standards is relatively stable in time, though the cognitive availability of particular contents in self-standards may change (Bąk \& Gołębiowska, 2012; Strauman, 1996).

As regards the meaning of the actual-ideal self-discrepancy, two views exist. According to the first one, the discrepancy is an indicator of maturity and the lack of defensive tendencies (Drożdżowicz, 2000). In the second view, the discrepancy is treated primarily as an indicator of maladjustment (Harter, 1996; Higgins, 1987; Rogers, 1984). Research has shown, for example, that constructive coping with stress - through actions aimed changing the stressful situation and searching for a positive influence of the event on personal development - is related to small self-discrepancy (Poon \& Lau, 1999). Some self-discrepancy is necessary in order to know what to strive for. However, self-discrepancy that is too large involves negative states, a sense of hopelessness, and tension (Harter, 1996). Achieving a particular standard results in diminishing self-discrepancy, 
but as people set themselves new goals, that situation does not last long (Carver $\&$ Scheier, 1998; Silvia \& Duval, 2001). It therefore seems that the optimal discrepancy between the current state and possible future selves ensures both motivation and well-being.

Likewise, in the context of motivation for change, balance between positive and negative future selves is important. Positive future selves (what one wants to be like) give direction to the person's strivings and give energy, building hope for the future. Negative possible selves (what one does not want to be like) show the consequences of a lack of perseverance and thus reinforce motivation to avoid undesirable states (Oyserman \& Markus, 1990). Research results confirm that individuals showing a higher level of balance between positive and negative self-standards undertake a larger number of activities to achieve these standards than individuals with a lower level of balance (Niemiec, 2012). Research also shows that individuals with a prevalence of avoidance processes exhibit a higher level of fear and more physical ailments than those with a prevalence of approach processes (Emmons, 1996; as cited in Carver \& Scheier, 1998); they also display pessimism, low self-esteem, and depression (Coats, Janoff-Bulman, \& Alpert, 1996).

Research suggests, too, that positive future self-concepts may perform the function of self-protection. In a failure situation, a person may fall back on positive possible selves. It was found (Markus \& Nurius, 1986) that individuals who had experienced a crisis in their life and still felt they were under its influence had not only negative actual self but also more negative possible selves activated. In contrast, individuals who had experienced a crisis but were already out of it generated positive possible self-concepts and evaluated them as more probable than did individuals from the control group, who had not experienced a crisis. There are two possible interpretations of these results. According to one of them, individuals who are in a positive condition after a crisis owe this precisely to the fact that the crisis is over and this is why they are able to create positive future self-concepts. But it may have been the ability to build positive future selves that allowed them to overcome the crisis.

\section{Change in the self in the course of psychotherapy}

The main schools of psychotherapy (cf. Grzesiuk, 2005) suggest that effective psychotherapy should lead, among other things, to an increase in the consistency and integration of the self. Research on self-concept clarity (Campbell et al., 1996) does not give a clear picture of the influence of psychotherapy on this 
aspect of self-integration. Roepke and colleagues (2011) carried out a study on patients diagnosed with borderline personality disorders treated using the dialectical behavioral therapy as compared to waiting group patients; they demonstrated that psychotherapy significantly increased the level of self-concept clarity. Another study (Styła, Jędrasik-Styła, \& Krawczyk, in preparation), carried out on a group of patients diagnosed with personality disorders and neurosis (participating in intensive group psychotherapy conducted in an eclectic manner) revealed that self-concept clarity increased exclusively in those patients who had initially showed a low level of self-concept clarity. The change in self-concept clarity following therapy was connected with a change in self-esteem, in neurosis symptoms, and in neurotic personality traits. Research results suggest that a change in self-concept clarity as a result of psychotherapy may depend on the patient's initial self-integration. This is consistent with results showing that self-concept clarity does not change in healthy people even in moments of important changes in life, but there is a difference in self-concept clarity between healthy individuals and those suffering from disorders. Patients with depression, anxiety, or schizophrenia have lower self-concept clarity (Huflejt-Łukasik, 2010).

Research testing the self-discrepancy theory (Higgins, 1987) shows that in the course of psychotherapy there occurs a significant reduction of the discrepancy between the actual self and the ideal self. In the research carried out by Strauman and colleagues (2001) such a result was found for patients with depression after participation in cognitive-behavioral and interpersonal psychotherapy. No such effect was found in the case of discrepancy between the actual self and the ought self. What is interesting is that in depressive patients who did not take part in psychotherapy but used pharmacotherapy symptomatic change was also observed, but it did not affect the magnitude of self-discrepancy.

Another study (Philips, Raiford, \& El Batrawi, 1965) - testing Rogers's theory - suggests that psychotherapy does not increase the similarity between the actual self and the ideal self in the whole group of patients. Truax, Schuldt, and Wargo (1968) interpret this result as showing that psychotherapy leads to an increase in consistency between the actual self and the ideal self only in those people in whose case it has been effective. Their research indicates that individuals who did not use psychotherapy experienced an intensification of tension and an increase in personality maladjustment, measured (among other tools) using the MMPI.

In other studies, too, it was observed that after effective psychotherapy the discrepancy between the actual self and the ideal self decreased in patients with neurotic and personality disorders (Rakowska, 2006) and so did the discrepancy 
between the actual self and the ought self (Elliott, 2008). Those changes correlated with a reduced intensity of depression, general anxiety, and social anxiety. A decrease in self-discrepancies as a result of psychotherapy was also observed in a group of elderly depressive patients (Pemberton, 2009). It is also worth adding that the actual self underwent change in psychotherapy and that the actual-ideal self-discrepancy decreased where it had been large (Rakowska, 2006). This did not happen in the case of small self-discrepancies, which may be understood as performing motivational functions.

As regards depressive people, when faced with information that carried a threat to the self, they started to compare the actual self with the ideal self, which showed the discrepancies between them (Kinderman, Prince, Waller, \& Peters, 2003). This result may be interpreted as pointing to the protective role of future self-concepts. Research also informs us that people with mental disorders are characterized by a rigid structure of the ideal self (weakly centralized, with many interrelated self-standards), which is connected with a lower flexibility of changes in the ideal self and with the occurrence of anxiety (Huflejt-Łukasik, 2010).

There are also data concerning changes in the repertoire of possible selves in the course of psychotherapy. Dunkel, Kelts, and Coon (2006) investigated the number of possible selves generated at successive stages of the change. They discovered that, as psychotherapy proceeds through successive stages (cf. Prochaska \& Norcross, 2006), first there is a substantial increase in the number of possible selves (which is connected with generating possible solutions to the problem), and then, after the decision concerning problem solution, the number of possible selves decreases (since implementing one of the options entails abandoning the alternative ones). The eventually chosen possible self and its content becomes an element of the actual self. An entirely new set of possible selves may, of course, appear in its place, promoting further personal development.

\section{CHANGES IN THE SELF IN THE COURSE OF PSYCHOTHERAPY IN THE LIGHT OF RESEARCH AND CONCLUSIONS FOR PRACTICE}

The presented concepts and studies indicate the directions of change in the self that are associated with positive results for the individual's functioning. The proposed guidelines for psychotherapeutic interventions should be treated as 
hypothetical and as a source of inspiration for and understanding of what may happen in the course of the psychotherapeutic process.

Thus, the concepts and studies show the significance of complete self-knowledge: the knowledge of what kind of person one is, what important goals one has, what one's traits are - the positive and negative aspects of self-concept - as well as what actions one can take. Accurate self-knowledge makes it possible to be active - to undertake more adjusted decisions and behaviors, taking into account one's capabilities and environmental demands. Researchers also inform us that change in the content of the self carries with it a change in self-structure, meaning that interventions in the course of psychotherapy that are aimed at changing self-perception carry with them a change in the structure of the self (e.g., increasing the complexity and differentiation of cognitive self-representations).

A change in self-structure is more strongly linked to adjustment and mental health than content change. What is more, a change in self-structure enables further change in the content even of those aspects of self-concept that are not being worked on directly in the course of psychotherapy. This is because the basis of self-structure change is constituted also by evaluative agreement (Vallacher \& Nowak, 2004). Vallacher and Nowak carried out a series of computer simulations investigating the self-organization of self-structure and found that even if selfaspects are not interrelated in terms of content, they will change the sign when grouped together. If an element was surrounded by others with the opposite sign, its sign changed to conform to that of the surrounding elements. It can therefore be postulated that by adding positive elements to the patient's self-perception in the course of psychotherapy, we potentially change also those negative contents that we do not directly work on.

Self-structure determines the accessibility of the content of the self, protecting the person from the negative effects of negative events. Self-concept differentiation, linked with a specific situational context, as well as the separation of positive and negative traits of a given self-aspect prevents generalization if a part of the self-concept is disturbed as a result of certain life events. It seems that being aware of both positive and negative self-aspects, but with emphasis on building a positive and differentiated self-representation, will not only buffer the negative effects of stress but also produce better self-knowledge.

What is therefore important in the course of psychotherapy is the work on building a complete and generally positive self-concept, including those negative aspects that make self-knowledge more complete and give direction to personal development. After all, research shows that balance between positive and negative representations of possible future selves results in greater activity in accom- 
plishing goals desirable for the self. Regardless of this, what needs stressing is the importance of a positive future self-concept, such as the ideal self, which may perform a protective and stabilizing function within the self also in the face of difficulties or crises, since it contains important goals that the person can identify with in a crisis situation. What is more, according to the theory of possible selves, a person may, in a situation of crisis, create additional imaginary representations of positive future self-concept, which also has a protective function. However, this relationship still needs empirical verification.

What is important in the context of psychotherapeutic work, which consists in getting to know oneself, is identifying the self-aspects that are central for a person and have a greater significance than others. Research shows that selfconcept is subject to change under the influence of experiences. This helps people adapt to changes as well as develop. At the same time, possessing contents central to the self stabilizes the sense of identity. We know that precisely this role is played by the ideal self and that it is the actual self that changes in the course of successful psychotherapy, reducing the discrepancy between the actual self and the ideal self. Probably, in the course of successful psychotherapy the clients discover that they are closer to their ideals than they thought, or undertake efforts for this to happen. Although no direct empirical data are currently available, it is necessary to consider a situation in which the unrealistic ideal self serves to protect identity and the change in the course of psychotherapy will consist in building a stable positive self-concept as well as in making the ideal self more realistic (cf. Huflejt-Łukasik, 2010).

We know that, to some degree and in certain circumstances, possible selves also undergo change. Consequently, the change in psychotherapy may be based on the exploration of possible future visions of oneself. If possible selves influence changes in the person's functioning, this opens the doors to using the knowledge about possible selves as inspiration for therapeutic interventions broadening the repertoire of the client's possible self-concepts. Based on this idea, it is possible to encourage clients to enter new contexts, unknown to them before, which may prepare them for new kinds of activity and new roles in life.

If, however, the source of problems is an unrealistic self-standard, then efforts to meet it will be ineffective and may even be harmful. A therapeutic intervention consisting in reflection on the expectations one has regarding oneself may lead to changing these expectations and improve the person's psychological condition without changing his or her behavior (cf. Duval \& Lalwani, 1999). Naturally, the effectiveness of such an intervention would depend on ensuring the client's emotional security and preparing the ground for the change, as re- 
search results show that unrealistic self-standards may serve to protect self-concept integration, even if the client is aware that achieving the goal is not very realistic (cf. Huflejt-Łukasik, 2010).

It is important that there should be a balance between differentiation and integration processes in the changes that the self undergoes. This prevents negative fragmentation or excessively strong integration that would hinder desirable change (Huflejt-Łukasik, 2010). In certain circumstances, self-reflection (also in the course of psychotherapy) may diminish the consistency of the self (Vallacher \& Nowak, 2004). If an important element, though characterized by a different value, becomes included in the self, it will affect the adjacent elements, increasing the area of a different value. This would result in areas of ambivalence within the self. Research results and examples from psychotherapy show, however, that such a situation may foster gradual change of the negative self-concept into a more positive one. Depressive people have few available positive aspects in their self-concept. They break free from depression if it is the positive self-aspects that become central to them (Pelham, 1991).

Is it possible for a change to occur in the course of psychotherapy without being accompanied by a change in the self? If mental health and effective selfregulation require up-to-date and broad self-knowledge taking new experiences into account, then psychotherapy, by definition, always involves a change in the self, even if the therapist consciously works to influence different aspects of the person's functioning. Regardless of the aim of psychotherapy, the psychotherapist should be aware of what influence the proposed therapeutic interventions have on changes in the client's self. This is because, regardless of the psychotherapist's and the client's intentions, psychotherapy always involves change regarding both the content (more adaptive content of self-schemata) and the structure of the self (cf. Styła, 2012). Change in the content of the self may be a slight modification or a major restructuring. As long as they have an adaptive character, both types of change should ultimately lead to an increase in the integration of self-structure, understood as a clearly and firmly defined, internally consistent self-concept, stable in time. Still, these tendencies as well as others concerning changes in the self in the course of psychotherapy require extensive empirical verification. The issues of changes in the self appear to be crucial in the context of psychotherapy. The existing theories and previous studies in the field of cognitive psychology and personality psychology provide data to explain what takes place in the course of psychotherapy and make it possible to select the desirable interventions. There are few studies that show the mechanisms and dynamics of change in the context of psychotherapeutic treatment - that is, the areas and 
depth of change in the self depending on the aims and interventions undertaken in psychotherapy. This direction of research should therefore be considered as the next step to take in investigating these issues. A further step could be to test the effectiveness of specific interventions aimed at producing changes in the self, together with the outcomes ascribed to them.

\section{REFERENCES}

Bak, W. (2014). Self-standards and self-discrepancies. A structural model of self-knowledge. Current Psychology, 33, 155-173.

Bąk, W., \& Gołębiowska, N. (2012, September). Stabilna struktura niestabilnych treści. Statość $i$ zmienność $w$ samowiedzy. Poster presented at the 9th Convention of the Polish Society of Social Psychology (PSPS), Sopot.

Campbell, J. D., Assananad, S., \& Di Paula, A. (2003). The structure of self-concept and its relation to psychological adjustment. Journal of Personality, 71, 115-140.

Campbell, J. D., Assananad, S., \& Di Paula, A. (2004). Cechy strukturalne pojęcia Ja a przystosowanie. In A. Tesser, R. B. Felson, \& J. M. Suls (Eds.), Ja i tożsamość (pp. 70-88). Gdańsk: Gdańskie Wydawnictwo Psychologiczne.

Campbell, J. D, Trapnell, P. D, Heine, S. J., Katz, I. M., Lavallee, L. F., \& Lehman, D. R. (1996). Self-concept clarity: Measurement, personality correlates, and cultural boundaries. Journal of Personality and Social Psychology, 70, 141-156.

Carver, C. S., \& Scheier, M. F. (1998). On the self-regulation of behavior. Cambridge: Cambridge University Press.

Coats, E. K., Janoff-Bulman, R., \& Alpert, N. (1996). Approach versus avoidance goals: Differences in self-evaluation and well-being. Personality and Social Psychology Bulletin, 22, 1057-1067.

Drożdżowicz, L. (2000). Struktura „Ja” w schizofrenii. Psychoterapia, 115(4), 21-34.

Dunkel, C. S., Kelts, D., \& Coon, B. (2006). Possible selves as mechanisms of change in therapy. In C. Dunkel, J. Kerpelman (Eds.), Possible selves. Theory, research and applications (pp. 187-204). New York: Nova Science Publishers.

Duval, T. S., \& Lalwani, N. (1999). Objective self-awareness and causal attributions for self-standard discrepancies: Changing self or changing standards of correctness. Personality and Social Psychology Bulletin, 25, 1220-1229.

Duval, T. S., \& Wicklund, R. A. (1972). A theory of objective self-awareness. New York: Academic Press.

Elliott, K. L. (2008). The relation of self-discrepancy to anxiety and depression as psychotherapy change measures. Dissertation Abstracts International: Section B: The Sciences and Engineering, 68(9-B), 6301.

Erikson, M. G. (2007). The meaning of the future: Toward a more specific definition of possible selves. Review of General Psychology, 11, 348-358.

Frazier, L. D., Hooker, K., Johnson, P. M., \& Kaus, C. R. (2000). Continuity and change in possible selves in later life: A 5-year longitudinal study. Basic and Applied Social Psychology, 22, 237-243.

Gara, M. A., Woolfolk, R. L., Cohen, B. D., Goldston, R. B., Allen, L. A., \& Novalany, J. (1993). Perception of self and other in major depression. Journal of Abnormal Psychology, 102, 93-100. 
Grzesiuk, L. (Ed.) (2005). Psychoterapia. Teoria. Warsaw: Eneteia.

Harter, S. (1996). Historical roots of contemporary issues involving self-concept. In B. A. Bracken (Ed.), Handbook of self-concept. Developmental, social, and clinical considerations (pp. 1-37). New York: John Wiley \& Sons.

Higgins, E. T. (1987). Self-discrepancy: A theory relating self and affect. Psychological Review, 94, 319-340.

Hoyle, R. H., \& Sherrill, M. R. (2006). Future orientation in the self-system: Possible selves, self-regulation, and behavior. Journal of Personality, 74, 1673-1696.

Huflejt-Łukasik, M. (2010). Ja i procesy samoregulacji: Różnice między zdrowiem a zaburzeniami psychicznymi. Warsaw: Wydawnictwo Naukowe Scholar.

James, W. (1890). The principles of psychology. New York: Holt.

Kinderman, P., Prince, S., Waller, G., \& Peters, E. (2003). Self-discrepancies, attentional bias and persecutory delusions. British Journal of Clinical Psychology, 42, 1-12.

Leary, M. R., \& Tangney, J. P. (2003). The self as an organizing construct in the behavioral and social sciences. In M. R. Leary \& J. P. Tangney (Eds.), Handbook of self and identity (pp. 314). New York: The Guilford Press.

Linville, P. W. (1985). Self-complexity and affective extremity: Don't put all of your eggs in one cognitive basket. Social Cognition, 1, 94-120.

Linville, P. W. (1987). Self-complexity as a cognitive buffer against stress-related illness and depression. Journal of Personality and Social Psychology, 52, 663-676.

Markus, H. (1977). Self-schemata and processing information about the self. Journal of Personality and Social Psychology, 35, 63-78.

Markus, H., \& Nurius, P. (1986). Possible selves. American Psychologist, 41, 954-969.

Markus, H., \& Wurf, E. (1987). The dynamic self-concept: A social psychological perspective. Annual Review of Psychology, 38, 299-337.

Marsh, H. W., \& Ayotte, V. (2003). Do multiple dimensions of self-concept become more differentiated with age? The differential distinctiveness hypothesis. Journal of Educational Psychology, 95, 687-706.

Morgan, H. J., \& Janoff-Bulmann, R. (1994). Positive and negative self-complexity: Patterns of adjustment following traumatic versus non-traumatic life experience. Journal of Social and Clinical Psychology, 13, 63-85.

Niemiec, M. (2012). Pozytywne i negatywne standardy Ja a dziatania podejmowane $w$ celu ich osiagnięcia oraz dobrostan psychiczny osoby (Unpublished master's thesis). University of Warsaw, Faculty of Psychology, Warsaw.

Oyserman, D., \& Markus, H. R. (1990). Possible selves and delinquency. Journal of Personality and Social Psychology, 59, 112-125.

Pelham, B. W. (1991). On the benefits of misery: Self-serving biases in the depressive self-concept. Journal of Personality and Social Psychology, 61, 670-681.

Pemberton, E. D. (2009). The relationship between self-discrepancy, depression severity, and psychotherapy treatment in depressed older adults. Dissertation Abstracts International: Section B: The Sciences and Engineering, 69(8-B), 5047.

Phillips, E. L., Raiford, A., \& El-Batrawi, S. (1965). The Q sort reevaluated. Journal of Consulting Psychology, 29, 422-425.

Poon, W.-T., \& Lau, S. (1999). Coping with failure: Relationship with self-concept discrepancy and attributional style. The Journal of Social Psychology, 139, 639-653. 
Prochaska, J. O., \& Norcross, J. C. (2006). Systemy psychoterapeutyczne. Analiza transteoretyczna. Warsaw: Health Psychology Institute, Polish Psychological Association (PTP).

Rakowska, J. M. (2006). Sukces i porażka terapii krótkoterminowej. Warsaw: Wydawnictwo Naukowe Scholar.

Roepke, S., Schröder-Abé, M., Schütz, A., Jacob, G., Dams, A., Vater, A., Rüter, A., Merkl A., Heuser I., \& Lammers C. H. (2011). Dialectic behavioural therapy has an impact on self-concept clarity and facets of self-esteem in women with borderline personality disorder. Clinical Psychology and Psychotherapy, 18, 148-158.

Rogers, C. (1984). Teoria terapii osobowości i relacji interpersonalnych rozwinięta w oparciu o podejście skoncentrowane na kliencie. Nowiny Psychologiczne, 2-3, 1-91.

Showers, C. J. (1992). Evaluative integrative thinking about characteristics of the self. Personality and Social Psychology Bulletin, 18, 719-729.

Showers, C. J., Abramson, L. Y., \& Hogan, M. E. (1998). The dynamic self: How the content and structure of the self-concept change with mood. Journal of Personality and Social Psychology, 75, 478-493.

Showers, C. J., \& Kling, K. C. (1996). Organization of self-knowledge: Implications for recovery from sad mood. Journal of Personality and Social Psychology, 70, 578-590.

Showers, C. J., \& Zeigler-Hill, V. (2003). Organization of self-knowledge: Features, functions, and flexibility. In M. R. Leary \& J. P. Tangney (Eds.), Handbook of self and identity (pp. 47-67). New York: The Guilford Press.

Silvia, P. J., \& Duval, T. S. (2001). Objective self-awareness theory: Recent progress and enduring problems. Personality and Social Psychology Review, 5, 230-241.

Strauman, T. J. (1996). Stability within the self: A longitudinal study of the structural implications of self-discrepancy theory. Journal of Personality and Social Psychology, 71, 1142-1153.

Strauman, T. J., Kolden G. G., Stromquist V., Davis N., Kwapil L. Heerey E., \& Schneider K. (2001). The effects of treatments for depression on perceived failure in self-regulation. Cognitive Therapy and Research, 25, 693-712.

Strauss, R., \& Goldberg, W. A. (1999). Self and possible selves during the transition to fatherhood. Journal of Family Psychology, 13, 244-259.

Styła, R. (2012). Change in self-concept differentiation after psychotherapy and its relation to psychological maladjustment. Psychological Reports, 110, 397-402.

Styła, R., Jędrasik-Styła, M., \& Krawczyk, K. (in preparation). Does self-concept clarity change after psychotherapy? How is it related to psychological maladjustment?

Suchańska, A., \& Worach, A. (2013). Złożoność koncepcji siebie a poczucie tożsamości. Roczniki Psychologiczne, 16(2), 199-215.

Truax, Ch. B., Schuldt, W. J., \& Wargo, D. G. (1968). Self-ideal concept congruence and improvement in group psychotherapy. Journal of Consulting and Clinical Psychology, 32, 47-53.

Vallacher, R. R, \& Nowak, A. (2004). Krajobrazy autorefleksji: Mapowanie szczytów i dolin oszacowań własnej osoby. In A. Tesser, R. B. Felson, \& J. M. Suls (Eds.), Ja i tożsamość (pp. 4369). Gdańsk: Gdańskie Wydawnictwo Psychologiczne.

Wollfolk, R. L., Novalany, J., Gara, M. A., Allen, L. A., \& Polino, M. (1995). Self-complexity, self-evaluation, and depression: An examination of form and content within the self-schema. Journal of Personality and Social Psychology, 68, 1108-1120. 